\title{
The Impact of Working Capital Management on Firm Value: Evidence from a Frontier Market
}

\author{
A.N. Hingurala Arachchi \\ Department of Finance, Faculty of Management Studies and Commerce \\ University of Sri Jayewardenepura \\ Wasantha Perera \\ Department of Finance, Faculty of Management Studies and Commerce \\ University of Sri Jayewardenepura \\ Ratnam Vijayakumaran (Corresponding author) \\ Department of Financial Management, Faculty of Management Studies and Commerce \\ University of Jaffna
}

Received: Oct. 7, 2017 Accepted: Nov. 24, $2017 \quad$ Published: December 24, 2017

doi:10.5296/ajfa.v9i2.12449 URL: https://doi.org/10.5296/ajfa.v9i2.12449

\begin{abstract}
Corporate finance literature and finance practitioners have the notion that the efficient working capital management (WCM) affects firm value. This study investigates the value effect of working capital management, using a sample of 44 listed companies on the Colombo Stock Exchange (CSE) over the period 2011-2015. The CSE is currently recognized as a high growth frontier market (FM) in the world. The efficiency of WCM is measured using the Cash Conversion Cycle (CCC) and its components while firm value is measured by the Tobin $\mathrm{Q}$ ratio. The firm size, leverage and sales growth are used as the control variables. Using panel data regression methodology (the pooled OLS and fixed effects regressions), the study finds that $\mathrm{CCC}$ is inversely related to Tobin Q, suggesting that managers can create value for their shareholders by efficiently managing investment in working capital of their firms.
\end{abstract}

Keywords: Working capital management, firm value, Tobin Q, cash conversion cycle, panel data, Sri Lanka.

JEL Classification: $\mathrm{D} 22, \mathrm{G} 31, \mathrm{G} 32$ 


\section{Introduction}

Working capital management (WCM) has an important role in attaining firm's ultimate goal of shareholder wealth maximization since it affects both profitability and liquidity of firms. Unlike the relationship between long term financing and firm value, the relationship between WCM and firm value has not received much attention in the empirical research, though poor working capital management has been identified as the main reason for the failure of most firms (Smith, 1978). This may occur due to the fact that working capital decisions are made frequently, and they are routine in nature and are reversible over time (Pratap Singh \& Kumar, 2014). Most researchers failed to identify the significant contribution of WCM to attain the ultimate goal of shareholder value maximization (Baker, Kumar, Colombage \& Singh, 2017). Yet, it has gained much attention as a field of research after the recent global financial crisis which occurred in 2007-2009.

Working capital can be identified as the balance between current assets and current liabilities (Pass \& Pike, 1984).WCM decisions involve choice of amount and composition of current asset as well as the financing of these assets. Working capital allows firms to adapt to the dynamic business conditions; therefore, proper management of working capital becomes essential as it has direct impact on financial health and operational success of firm. The company's liquidity position is especially important in today's globalized and highly competitive business environment, as well as in times of economic and financial hardships such as recent financial crises characterized by decreasing cash inflows and deteriorating market conditions. Maintaining high level of current assets may increase firm's liquidity but at the expense of firm's profitability. Efficient working capital decisions must address this mismatch between asset and liability and utilize working capital in a way that it maximizes the shareholder wealth (Padachi, 2006).Shin and Soenen (1998) suggest that the managers can create value for their shareholders by efficiently managing working capital of their firms. This implies that proper management of working capital would have an impact not only on accounting performance of firm but also on the market performance of firm. Therefore, managers should consider a trade-off between efficiency and risk when making working capital decisions.

Although the notion that efficiency of WCM affects firm value seems to enjoy wide acceptance, the empirical evidence on the value effect of working capital investment is scarce (Baños-Caballero, García-Teruel, \&Martínez-Solano, 2014). Therefore, this study focuses on the value effect of WCM from a frontier market perspective, namely Sri Lanka. To achieve this objective, the study consider Tobin $\mathrm{Q}$ ratio as a proxy for firm value and the cash conversion cycle (CCC), the most commonly used measure of working capital management efficiency. Firms in emerging market are comparatively smaller in size. Further, the Sri Lankan nascent capital market is characterized by high level of asymmetric information and agency problems like other Asian capital markets compared with the markets of developed countries and thus the flow of additional capital is rather restricted for the firms in Sri Lanka (Perera, \& Wickremasinghe, 2010; Eswaran, 2015; Vijayakumaran, 2015; Dixon, Guariglia, and Vijayakumaran, 2015). Therefore, it becomes vitally important for the firms in Sri Lanka to manage working capital efficiently and release the fund that may be unnecessarily tied up 
in working capital to fund the long term projects and the expansion of their operations. Using a panel of 44 companies listed in CSE for the period of 2011-2015, the study finds that CCC is negatively associated with Tobin Q, suggesting that managers can increase their firm value by reducing the cash conversion cycle to a reasonable minimum. In other word, market provides higher valuation to the companies with the efficient working capital management.

The rest of the paper is organised as follows. The next section reviews related literature and provides our testable hypothesis. The methodology used in this study is discussed in Section 3. In Section 4, we discuss the sample and data and describe descriptive statistics. Section 5 presents the empirical findings of the study and finally, Section 5 provides the summary and conclusion.

\section{Prior literature and hypothesis development}

Lewellen, McConnel, and Scott (1980) demonstrate that under perfect financial markets, trade credit decisions are independent of firm value. However, in reality capital markets are imperfect due to factors like asymmetric information and agency problems and, consequently, several papers show that trade credit and inventories influence firm value (see, for instance, Bao \& Bao, 2004; Emery, 1984). Maness and Zietlow (2004) develop two models of value creation that incorporate effective short-term financial management activities. Similarly, Schiff and Lieber (1974), Sartoris and Hill (1983), and Kim and Chung (1990) model the effects of working capital management practices on firm value; yet, they do not provide empirical evidence on whether firms actually do maximize their value by their working capital management choices. Although the notion that efficiency of WCM affects firm value seems to enjoy wide acceptance, the empirical evidence on the value effect of working capital investment is scarce (Baños-Caballeroet al., 2014).

Most of the previous empirical research has focused on the working capital determinants (e.g., Garcia-Teruel \& Solano, 2010;Anagnostopoulou, 2012), policy practices (e.g., Afza \& Nazir, 2007;Pandey, Gupta \&Perera, 1997; Perera, \& Wickremasinghe, 2010; Bei \& Wijewardena, 2012) and relationship between WCM and accounting performance of companies (e.g., Deloof 2003;Padachi 2006). Majority of the empirical studies confirm a negative relationship between WCM measures and accounting profitability measures (e.g., Deloof, 2003;Lazaridis and Tryfonidis,2006; Garcia-Teruel and Martinez Solano, 2007;Jayarathne, 2014).

There are considerable amount of research studies that investigate relationship between cash holdings and firm value. For instance, Autukaite and Molay (2011) find that shareholders of French companies undervalue cash holdings and net working capital since excess working capital means money tied up in current assets that does not generate a return; instead, an additional euro invested in net operating working capital than usual level decreases firm value. This can be considered as indirect conformation of the agency cost of free cash flow (Jenson 1986). Further, they find that shareholders of a highly levered firm tend to give less value to cash holdings and working capital since its returns are used to pay for debt holders. Pinkowitzet al. (2006), Lee and Lee (2009) find negative association between cash holdings and firm value while Bates et al.(2009), Chen (2009) suggest that financial market value liquidity indicating a positive relationship between cash holding and firm value in their 
studies. Pinkowitz and Williamson (2007) report that value of cash holdings differs on several factors and firms with high growth opportunities and operating risk tend to have high value to their cash holdings.

The impact of efficiency of working capital management on market performance of the firms is overlooked. In fact, only a handful of studies investigate how the efficiency of WCM affects firm value. For example, studying a sample of 172 listed Malaysia companies for the period of 2003-2007, Mohamad and Saad (2010) provide empirical evidence on the effect of efficiency of WCMon market value and profitability. Their results show that there is a significant negative association between working capital management efficiency variables and firm's market value and profitability. These results indicate the importance of efficient working capital management to increase firm's market value and profitability and that this fact should be considered when formulating company's strategic and operational planning in order to operate it effectively and efficiently. Similarly, Focusing on a sample of 75 manufacturing companies listed on Istanbul stock exchange market for the period of 2002-2009, Vural et al. (2012) examine the impact of WCM on both internal and external performance of the firm using Tobin $\mathrm{Q}$ as a proxy for market value and gross operating profit as a proxy for profitability. Their results show that there is a significant relationship between $\mathrm{CCC}$, accounts receivable period and profitability while Tobin $\mathrm{Q}$ shows insignificant relationship with working capital of the firms. Mona Al-Mwalla (2012) focus on a sample of 57 listed companies on Amman Stock Exchange for the period of 2001-2009 to examine the impact of working capital management policies on the firm's profitability and value. They conclude that a conservative policy regarding WCM shows a positive effect on the firm's profitability and value and vice versa. They also found that firm's size, growth and GDP shows a positive effect on the profitability and value.

Abuzayed (2012) use a sample of 52 non-financial firms of Amman stock market over the period 2000-2008 to examine the effect of WCM on firm performance. She uses two measures, namely accounting measure (profitability) and market based measure (Tobin Q)to measure firm performance and find that efficient WCM improves both firms' market value and profitability. More recently, Wasiuzzaman (2015) uses 192 Malaysian listed companies over the period 1999-2008 to examine the relationship between working capital management efficiency and firm value and the influence of financing constraints on this relationship. Her results show that improvements in working capital efficiency through reduction in working capital investments leads to higher firm value and this relationship is more pronounced in the financially constrained firms suggesting that firm value significantly increases by efficient management of working capital in financially constrained firms.

Although recent research has shown increasing interest on the relationship between WCM and firm value, only a study by Bandara \& Weerakoon Banda (2010) investigates the impact of working capital practices on firm value which is measured by market value added and economic value added in the context of Sri Lanka. Focusing a sample of 72 companies listed on CSE, they document that there is significant negative relationship between conservative WCM practices and market value added and moderate working capital practices yield higher market value added. Furthermore, their results show that economic value added decreases 
with aggressive working capital policy and firms following moderate working capital practices tend to improve both economic and market value added.

In sum, existing literature regarding impact of working capital management on firm value is very limited and particularly, in the context of Sri Lanka, no one has focused on the relationship between the efficiency of WCM and Tobin Q which is a commonly used proxy for firm value. Therefore, our study focuses on the linkage between the efficiency of WCM and firm value from a frontiers market, namely Sri Lanka.

\subsection{Hypothesis}

In this study, we use the cash conversion cycle as a comprehensive measure of working capital management efficiency. Since the cash conversion cycle is an inverse proxy for the WCM efficiency, we would expect a negative relationship between $\mathrm{CCC}$ and firm value.

$H_{1}$ : There is a negative relationship between the cash conversion cycle and firm value.

\section{Model Specification and Estimation methodology}

Purpose of this study is to examine the relationship between WCM efficiency and firm value of listed companies in Sri Lankan context. This section describes our regression model, definition of variables, and estimation methodology.

\subsection{Model specification}

In order to estimate the impact of WCM efficiency on firm value, we estimate the following econometric model:

$$
\mathrm{TQ}_{\mathrm{it}}=\beta_{0}+\beta_{1} \mathrm{CCC}_{\mathrm{it}}+\beta_{2} \mathrm{SIZE}_{\mathrm{it}}+\beta_{3} \mathrm{LEV}_{\mathrm{it}}+\beta_{4} \mathrm{SGR}_{\mathrm{it}}+\mathrm{v}_{\mathrm{t}}+\mathrm{v}_{\mathrm{j}}+\varepsilon_{\mathrm{it}}
$$

Where $i$ indexes firms, $t$ years. Table 1 provides definitions for all variables used in this paper. The error term in Equation (1) is made up of three components: $v_{t}$, a time-specific effect, which we control for by including time dummies capturing business cycle effects; $v_{j}$, an industry-specific effect, which we take into account by including industry dummies; and finally, $\varepsilon_{i t}$ is an idiosyncratic component. In addition, we estimate equation (1) by replacing $C C C$ with components of $C C C$, namely number of days accounts receivable, number of days inventory and number of days accounts payable in isolation.

In addition, we estimate following model with a firm specific fixed effects but it does not include industry effects.

$$
\mathrm{TQ}_{\mathrm{it}}=\beta_{0}+\beta_{1} \mathrm{CCC}_{\mathrm{it}}+\beta_{2} \mathrm{SIZE}_{\mathrm{it}}+\beta_{3} \mathrm{LEV}_{\mathrm{it}}+\beta_{4} \mathrm{SGR}_{\mathrm{it}}+\mathrm{v}_{\mathrm{i}}+\mathrm{v}_{\mathrm{t}},+\varepsilon_{\mathrm{it}}
$$

The error term in Equation (2) is made up of three components: $v_{i}$ is a firm-specific effect; $v_{t}$, a time-specific effect and finally, $\varepsilon_{i t}$ is an idiosyncratic component. We also estimate equation (2) by replacing $C C C$ with components of $C C C$, namely number of days accounts receivable, number of days inventory and number of days accounts payable in isolation. 


\subsubsection{Dependent variable}

In this study we use Tobin's Q to measure firm value. Tobin's $Q$ is the ratio of the market value of a company's assets (which is measured by the market value of its outstanding shares and book value of debt) divided by the book value of the company's assets.

\subsubsection{WCM efficiency variables}

The main independent variable is the cash conversion cycle (denoted by $C C C$ ) which is used as a comprehensive measure to capture the effect of firms' working capital efficiency on corporate performance (Deloof, 2003). The CCC links the time needed by firms to collect cash from customers with the time necessary in order to repay suppliers into one single measure (Deloof, 2003). The cash conversion cycle is as the sum of number of days accounts receivable plus number of days inventory minus number of days accounts payable. The components of CCC are calculated as follows. Number of day's accounts receivable is calculated as a ratio of accounts receivable times 365 divided by sales. Number of day's inventories is calculated as a ratio of inventories times 365 divided by cost of sales. Number of days accounts payable is accounts payable times 365 divided by cost of sales. We expect a negative relationship between number of day's accounts receivable (a measure of accounts receivable policy) and number of day's inventories and performance whereas a positive relationship between number of days accounts payable and performance.

\subsubsection{Control variables}

In line with previous studies, in addition our WCM variables, size (the natural logarithm of sales), sales growth ([this year's sales - previous year's sales]/previous year's sales), and the ratio of total debt to total assets (debt/total assets) are included as control variables in the regressions to control for a set of firm-specific observable characteristics that are likely to be correlated with firms' performance. 
Table 1. Definitions of variables

\begin{tabular}{|c|c|c|c|}
\hline Variables & Acronyms & Measurement & $\begin{array}{l}\text { Expected } \\
\text { relationship with } \\
\text { firm value }\end{array}$ \\
\hline \multicolumn{4}{|l|}{ Dependent Variables } \\
\hline Tobin's Q & $T Q$ & $\begin{array}{l}\text { (Market value of equity+book value of } \\
\text { liabilities)/ book value of total assets }\end{array}$ & \\
\hline \multicolumn{4}{|l|}{ WCM Variables } \\
\hline Cash conversion cycle & $C C C$ & $\begin{array}{l}\text { Aggregation of inventory, receivables and } \\
\text { payables days }\end{array}$ & - \\
\hline Accounts receivable days & $A R D$ & (Accounts receivables/sales) $* 365$ & - \\
\hline Inventory days & $I N V D$ & (Inventories/ cost of sales) $^{*} 365$ & - \\
\hline Accounts payables days & $A P D$ & (Accounts payables/ cost of sales)*365 & + \\
\hline \multicolumn{4}{|l|}{ Control Variables } \\
\hline Firm size & SIZE & The natural logarithm of sales & + \\
\hline Leverage & $L E V$ & $\begin{array}{l}\text { Total non-current liabilities divided by total } \\
\text { assets }\end{array}$ & - \\
\hline Salesgrowth & $S G R$ & $\begin{array}{l}\text { Difference between sales of end of year } t \text { and end } \\
\text { of year } t_{-1} \text {. }\end{array}$ & + \\
\hline
\end{tabular}

\subsection{Estimation methodology}

In this study, pooled Ordinary Least Square (OLS) and fixed effects regression are used to test the hypotheses. A pooled OLS (Ordinary Least Square) does not take into account the unobserved firm heterogeneity. In random effect model it is presumed that regression model intercept varies across entities, and this variation is assumed to be random and uncorrelated with the independent variables included in the model while in the fixed effects model assumes that there is correlation between error term and predictor variable. Therefore, fixed effect model removes the effect of time invariant characteristics from the model. We use the Hausman specification test to decide whether fixed effect method (FEM) or random effect method (REM) is econometrically a more appropriate approach to our data. Highly significant Hausman Chi-Square test statistics reveal systematic differences in coefficients between both models, which indicate highly significant firm-specific effects and thus showing that FEM provides better specification of our model relative to REM.

\section{Sample and descriptive statistics}

This section discusses sample and descriptive statistics of the dependent and independent variables used in this study.

\subsection{Data set and sample}

The data used in this study was collected from annual reports of companies which are published in the CSE website. Initially 88 firms were included in the sample and only 46 companies were selected based on the data availability for all variables for the period of 2010-2015. To reduce the influence of potential outliers, we exclude observations in the one 
percent tails of each of the regression variables. Final sample consist of 44 listed firms in CSE which is classified under manufacturing (20), health care (3), food and beverage (11), motors (5) and Chemicals and pharmaceuticals (5). Finally, after the screening process and computation of the variables, we end up with a panel of 194 firm-year observations for the period of 2011-2015 for our empirical analysis.

\subsection{Summary statistics}

Table 2. Summary statistics

\begin{tabular}{lcccccc}
\hline & Obs & Mean & Std. Dev. & Median & Min & Max \\
\hline Tobin's Q $\quad(T Q)$ & 194 & 1.92 & 1.84 & 1.40 & 0.24 & 13.62 \\
Cash conversion cycle $\quad(C C C)$ & 194 & 65.77 & 53.72 & 44.67 & 2.31 & 222.17 \\
Accounts receivable days $(A P D)$ & 194 & 52.00 & 34.19 & 34.02 & 6.39 & 160.53 \\
Inventory days (INVD) & 194 & 42.36 & 38.06 & 20.99 & 1.00 & 223.85 \\
Accounts payables days (ARD) & 194 & 28.58 & 28.11 & 50.61 & 1.15 & 242.55 \\
Firm size (SIZE) (Rs. billion) & 194 & 4.39 & 5.57 & 2.61 & 0.061 & 32.902 \\
Leverage (LEV) & 194 & 0.45 & 0.156 & 0.40 & 0.080 & 0.820 \\
Sales growth $(S G R)$ & 194 & 0.125 & 0.248 & 0.10 & -0.454 & 1.957 \\
\hline
\end{tabular}

Notes: See the Table 1 for definitions of the variables.

Table 2 presents descriptive statistics for the variables used in the analysis for our pooled sample. The pooled mean (median) Tobin's Q $(T Q)$ is $1.92(1.40)$. The average (median) cash conversion cycle is 65.77 days (44.67 days). Firms receive payment from their credit sales after on average of 52 days with a median of 34.02 days. It takes on average 42.36 days (median is 33.8 days) to sell inventory. Firms pay their suppliers after 28.58 days on average, (median is 50.61 days).

Turning to the control variables, average size of the sample firms measured by sales is about 4.39 billion rupees ( 2.61 billion rupees). The debt ratio has a mean and median value of $45 \%(40 \%)$, suggesting that about $45 \%$ of the sample firms' assets are financed by debt capital. The average (median) sales growth, measured as changes in sales, is $12.5 \%(10 \%)$. The large disparity between mean and median values for the components of the $C C C$ illustrates the dramatic variation in turnover ratios among the sample firms.

\section{Empirical results}

This section provides discussion of empirical results obtained from correlation and regression analysis.

\subsection{Correlation analysis}

Table 3 provides the Pearson correlation of coefficients for the pairs of variables of this study. It can be observed that $C C C$ has a significant negative relationship with Tobin $\mathrm{Q}(T Q)$ which is consistent with the literature that increase in time lag in cash conversion will negatively affect to the market performance of the firm. Inefficient payment collection from debtors would decrease the market value of firm which is evident by significant negative correlation between accounts receivables and $T Q$. As investors in financial markets are concerned about 
credit sales and late collection of debt payments since this indicates the inefficient liquidity management of firms. Similarly, as expected Inventory days (INVD) also exhibit a negative and significant relationship with $T Q$. Surprisingly, number of days accounts payable is not significantly associated with $T Q$.

Looking at the control variables, leverage depicts a significant negative relationship with $T Q$ reflecting higher amount of debt would cause an adverse influence on market value of the firm since higher leverage increases the financial risk of the firm. Furthermore, large firms have higher market value, exhibiting a positive significant correlation with $T Q$.

Finally, Table 3 suggests that given that the observed correlation coefficients are relatively low, multicollinearity should not be a serious problem in our study.

Table 3. Pearson correlation matrix

\begin{tabular}{lllllllll}
\hline & TQ & CCC & ARD & INVD & APD & SIZE & LEV & SGR \\
\hline$T Q$ & 1.00 & & & & & & & \\
$C C C$ & $-0.17^{* *}$ & 1.00 & & & & & & \\
$A R D$ & $-0.27^{* * *}$ & $0.70^{* * *}$ & 1.00 & & & & & \\
$I N V D$ & $-0.02^{*}$ & $0.66^{* * *}$ & $0.21^{* * *}$ & 1.00 & & & & \\
$A P D$ & 0.03 & $-0.17^{* *}$ & $0.17^{* *}$ & $0.35^{* * *}$ & 1.00 & & & \\
SIZE & $0.64^{* * *}$ & $-0.12^{*}$ & $-0.21^{* * *}$ & -0.03 & -0.05 & 1.00 & & \\
LEV & $-0.12^{*}$ & -0.08 & $-0.17^{* *}$ & 0.09 & 0.06 & $0.26^{* * *}$ & 1.00 & \\
$S G R$ & 0.18 & 0.02 & -0.05 & $0.13^{*}$ & 0.08 & 0.05 & 0.06 & 1.00 \\
\hline
\end{tabular}

Notes: Asterisks denote statistical significance at the $1 \%(* *), 5 \%(* *)$, or $10 \%(*)$ level, respectively. See the Table 1 for definitions of the variables.

\subsection{Multivariate analysis}

\subsubsection{Pooled OLS regression results}

Table 4 presents estimation results of pooled OLS regressions [see Eq. (1)]. Column 1 reports results of our regression model (1) where the dependent variable namely, Tobin's Q $(T Q)$ is regressed on $C C C$ and a set of control variables including firm size, leverage, sales growth and a set of year dummies and industry dummies. In addition, Columns 2-4 of Table 4 report results of the effect of components of $C C C$, namely number of days accounts receivable, number of days inventory and number of days accounts payable on firm value, respectively.

Firstly, the coefficient of $C C C$ is negative and statistically significant at the $5 \%$ level, supporting our hypothesis (H1). Since the CCC is an inverse proxy for the efficiency of WCM, this result provides strong evidence to the predicted negative relationship between $C C C$ and firm value (or equivalently, a positive relation between the efficiency of WCM and firm value). This implies that the shorter the time lag between the expenditure for the purchases of raw materials and the collection of sales of finished goods and the smaller the investment in working capital, the higher will be the firm value. This finding is consistent with the findings of Mohamad and Saad (2010), Abuzayed (2012), Wasiuzzaman (2015). As can be observed in Columns 2-4 of the Table 4, the coefficient associated with the accounts 
receivable (a measure of accounts receivable policy) $(A R D)$ is negative and significant at the $1 \%$ level. Similarly, the coefficient on days inventories on hand ((INVD) is negative and statistically significant at the $5 \%$ level. The coefficient on the number of days accounts payable $(A P D)$ is positive and statistically significant at the $10 \%$ level.

Table 4. Pooled OLS: the relationship between WCM and Tobin $Q$

\begin{tabular}{|c|c|c|c|c|}
\hline Regression Models & 1 & 2 & 3 & 4 \\
\hline \multirow{2}{*}{ Constant } & $-7.198 * * *$ & $-6.317 * * *$ & $-7.622 * * *$ & $-7.636 * * *$ \\
\hline & $(-3.140)$ & $(-2.770)$ & $(-3.30)$ & $(-3.330)$ \\
\hline \multirow{2}{*}{$C C C$} & $-.0 .038 * *$ & & & \\
\hline & $(-2.250)$ & & & \\
\hline \multirow{2}{*}{$A P D$} & & $-0.012 * * *$ & & \\
\hline & & $(-0.280)$ & & \\
\hline \multirow{2}{*}{$I N V$} & & & $-0.005^{* *}$ & \\
\hline & & & $(-2.213)$ & \\
\hline \multirow{2}{*}{$A R D$} & & & & $0.002 *$ \\
\hline & & & & $(1.805)$ \\
\hline \multirow{2}{*}{ SIZE } & $0.406^{* * *}$ & $0.386^{* * *}$ & $0.412 * * *$ & $0.414 * * *$ \\
\hline & $(3.780)$ & $(0.3 .640)$ & $(3.800)$ & $(3.830)$ \\
\hline \multirow{2}{*}{$L E V$} & $-0.635^{* *}$ & $-0.443 * *$ & $-0.506^{* *}$ & $-0.524 *$ \\
\hline & $(-1.991)$ & $(-2.151)$ & $(-2.050)$ & $(-0.1 .89)$ \\
\hline \multirow{2}{*}{$S G R$} & 0.086 & 0.166 & 0.220 & 0.097 \\
\hline & $(0.170)$ & $(0.633)$ & $(0.823)$ & $(0.896)$ \\
\hline Industry dummies & Yes & Yes & Yes & Yes \\
\hline Year dummies & Yes & Yes & Yes & Yes \\
\hline Adj R2 & 0.187 & 0.235 & 0.198 & 0.199 \\
\hline F-statistic & 4.02 & 4.68 & 3.76 & 3.79 \\
\hline Prob(F-statistic) & 0.000 & 0.000 & 0.000 & 0.000 \\
\hline
\end{tabular}

Notes: Asterisks denote statistical significance at the $1 \%(* * *), 5 \%(* *)$, or $10 \%(*)$ level, respectively. t-statistics which are based on cluster robust slandered error (clustered at the firm level)are reported in the parentheses. See the Table 1 for definitions of the variables.

The results of regressions (1) to (4) suggest that managers can increase firm value by improving the efficiency of working capital management (i.e., by reducing the number of days accounts receivable and inventories and by delaying the payment to the creditors).

Turning to the control variables, we observe that the estimated coefficient on firm size (SIZE) is positive and highly significant at the $1 \%$ level in all the models, suggesting that large firms enjoy economies of scale and are thus positively associated with firm value $(T Q)$. This finding is consistent with the finding of Jahfer (2015). The coefficient associated with leverage is negative and statistically significant at the $5 \%$ level, suggesting that the increase in financial risk associated with the leverage is not appealing to investors. Finally, sales 
growth $(S G R)$ is not significantly associated with firm performance at conventional levels. This finding is consistent with the finding of Jahfer (2015).

\subsubsection{Fixed effects regression results}

Table 5 presents estimation results of fixed effects regressions [see Eq. (2)]. Column 1 reports results of our regression model (2) where the dependent variable namely, Tobin's Q $(T Q)$ is regressed on $C C C$ and a set of control variables including firm size, leverage, sales growth and a set of year dummies. In addition, Columns 2-4 of the Table 5 report results of the effect of components of $C C C$, namely number of days accounts receivable, number of days inventory and number of days accounts payable on firm value, respectively.

Table 5. Fixed effects regression: the relationship between WCM and Tobin Q

\begin{tabular}{|c|c|c|c|c|}
\hline Regression Model & 1 & 2 & 3 & 4 \\
\hline Constant & $\begin{array}{l}-4.635 \\
(-0.990)\end{array}$ & $\begin{array}{l}-4.292^{*} \\
(-1.901)\end{array}$ & $\begin{array}{l}-4.159 \\
(-1.210)\end{array}$ & $\begin{array}{l}-4.208^{* *} \\
(-1.781)\end{array}$ \\
\hline$C C C$ & $\begin{array}{l}-0.001^{* *} \\
(-2.210)\end{array}$ & & & \\
\hline$A R D$ & & $\begin{array}{l}-0.004 * * \\
(-1.992)\end{array}$ & & \\
\hline$I N V$ & & & $\begin{array}{l}-0.003^{*} \\
(-1.948)\end{array}$ & \\
\hline$A P D$ & & & & $\begin{array}{l}0.001 \\
(0.928)\end{array}$ \\
\hline SIZE & $\begin{array}{l}0.236^{* * *} \\
(2.700)\end{array}$ & $\begin{array}{l}0.396 * * \\
(2.230)\end{array}$ & $\begin{array}{l}0.237 * * * \\
(2.670)\end{array}$ & $\begin{array}{l}0.249 * * * \\
(2.69)\end{array}$ \\
\hline$L E V$ & $\begin{array}{l}-0.410 * * \\
(-1.980)\end{array}$ & $\begin{array}{l}-0.431 * * \\
(-1.998)\end{array}$ & $\begin{array}{l}-0.462 * \\
(-1.894)\end{array}$ & $\begin{array}{l}-0.398 * * \\
(-2.100)\end{array}$ \\
\hline$S G R$ & $\begin{array}{l}0.105 \\
(0.853)\end{array}$ & $\begin{array}{l}0.500 \\
(1.090)\end{array}$ & $\begin{array}{l}0.086 \\
(0.971)\end{array}$ & $\begin{array}{l}0.099 \\
(0.851)\end{array}$ \\
\hline Firm fixed effects & Yes & Yes & Yes & Yes \\
\hline Year dummies & Yes & Yes & Yes & Yes \\
\hline Adj $R^{2}$ & 0.153 & 0.149 & 0.1486 & 0.149 \\
\hline F-statistic & 7.92 & 8.01 & 7.82 & 7.89 \\
\hline Prob(F-statistic) & 0.000 & 0.000 & 0.000 & 0.000 \\
\hline
\end{tabular}

Notes: Asterisks denote statistical significance at the $1 \%(* * *), 5 \%(* *)$, or $10 \%(*)$ level, respectively. t-statistics which are based on cluster robust slandered error (clustered at the firm level)are reported in the parentheses. See the Table 1 for definitions of the variables.

First, the coefficient of $C C C$ is negative and statistically significant at the $5 \%$ level, supporting our hypothesis (H1). This result once again provides strong evidence to the predicted negative relationship between $C C C$ and firm value. As can be observed in Columns 2-4 of the Table 5, the coefficient associated with the accounts receivable $(A R D)$ is negative and significant at the $5 \%$ level. Similarly, the coefficient on days inventories on hand $((I N V D)$ is negative and statistically significant at the $5 \%$ level. The coefficient on the 
number of days accounts payable $(A P D)$ is positive but not statistically significant at the conventional levels. These results indicate that excess cash tied- upin inventories and accounts receivables is perceived as working capital management inefficiencies by the market causing a reduction in firm value. As for the control variables, they show qualitatively similar results to the ones observed in the Table 4.

Overall, the results of regressions (1) to (4) suggest that managers can increase firm value by improving the efficiency of working capital management by reducing the number of days accounts receivable and inventories. The number of days accounts payable $(A P D)$ does not affect firm value.

\section{Conclusions}

Investments in working capital involve a trade-off between profitability and liquidity and thus the efficient working capital management affects firm value. Although a large number of previous empirical studies report that firm profitability is influenced by the efficient WCM, only a handful of studies examine the effect of WCM on firm value. Therefore, this study focuses on the value effect of WCM efficiency.

Using a panel of 44 companies listed in CSE for the period of 2011-2015, we find that the cash conversion cycle is negatively associated with Tobin Q, suggesting that efficient working capital management leads to an increase in the market value of the firms and thus helps to increase shareholder wealth. In other words, financial market will penalize the firms that fail to manage their working capital properly. Our results also suggest that managers can increase the shareholder wealth by reducing the number of days in accounts receivable and inventories.

\section{References}

Abuzayed, B. (2012). Working Capital Management and Firm's Performance in Emerging Markets: The Case of Jordan. International Journal of Managerial Finance, 8(2), 155-179. https://doi.org/10.1108/17439131211216620

Afza, T., \& Nazir, M. S. (2007). Is it Better to be Aggressive or Conservative in Managing Working Capital?. Journal of Quality and Technology Management, 3(2), 1-15.

Al-Mwalla, Muna. (2012). The impact of Working Capital Management Policies on firm's Profitability and Value: the case of Jordan. International Research Journal of Finance and Economics, 85, 147-153.

Anagnostopoulou, S. (2013). Working Capital Management and Firm Listing Status. Multinational Finance Journal, Forthcoming, 16(3), 261-301.

Autukaite-Eric Molay, R. (2013). Cash Holdings, Working Capital and Firm Value: Evidence From France, International Conference of the French Finance Association (AFFI), 1-22. https://doi.org/10.2139/ssrn.183690 
Baker, H. K., Kumar, S., Colombage, S., \& Singh, H. P. (2017). Working capital management practices in India: survey evidence. Managerial Finance, 43(3), 331-353. https://doi.org/10.1108/MF-07-2016-0118.

Bandara, R. M. S, \& Weerakoon Banda, Y. K., (2008). Impact of Working Capital Management Practices on Firm Value, Working paper, Department of Accountancy, Faculty of Commerce \& Management Studies, University of Kelaniya.

Banos-Caballero, S., García-Teruel, P. J., \& Martínez-Solano, P. (2010). Working capital management in SMEs. Accounting and Finance, 50(3), 511-527. https://doi.org/10.1111/j.1467-629X.2009.00331.x

Bates, T.W., Kahle, K.M., \& Stulz, R.M. (2009). Why do US firms hold so much more cash than they used to?. Journal of Finance, 64(5), 1985-2021. https://doi.org/10.1111/j.1540-6261.2009.01492.x

Bei, Z., \& Wijewardana, W. P. (2012). Procedia Social and Behavioral Sciences Working capital policy practice: Evidence from Sri Lankan companies. Procedia -Social and Behavioral Sciences, 0, 0-0. https://doi.org/10.1016/j.sbspro.2012.03.251

Chen, N. (2009). Corporate liquidity in emerging markets: a retrospect of Asian financial crisis. 17th Conference on the Theories and Practices of Securities and Financial Markets, Kaohsiung.

Deloof, M. (2003). Does working capital management affect profitability of Belgian firms?. Journal of business finance \& Accounting, 30(3-4), 573-588.

Dixon, R., Guariglia, A., \& Vijayakumaran, R. (2015). Managerial ownership, corporate governance and firms' exporting decisions: evidence from Chinese listed companies. The European Journal of Finance, 1-39.

Eswaran, V. (2015). Shareholders wealth effects of rights and bonus issues: Evidence from Sri Lanka.International Journal of Accounting and Business Finance, 1(2),1-13, 2015.

Jahfer, A. (2015). Effects of working capital management on firm. International Journal of Managerial and Financial Accounting, 7(1), 26-37.

Jayarathne, T. A. N. R. (2014, February). Impact of working capital management on profitability: Evidence from listed companies in Sri Lanka. In Proceedings of the 3rd International Conference on Management and Economics, 26, 27.

Jensen, M.C., \& Meckling, W. H., (1976).Theory of the firm: managerial behaviour, agency costs and ownership structure. Journal of Financial Economics, 3, 305-360.

Kieschnick, R., Laplante, M., \& Moussawi, R. (2013). Working capital management and shareholders' wealth. Review of Finance, 17(5), 1827-1852.

Lee, K.W., \& Lee, C.F. (2009). Cash holdings, corporate governance structure and firm valuation. Review of Pacific Basin Financial Markets and Policies, 12(3), 475-508. 
Martínez-Solano, P., \& García-Teruel, P. J. (2007). Effects of Working Capital Management on SME Profitability. International Journal of Managerial Finance, 3(2), 164-177. https://doi.org/10.2139/ssrn.894865

Maness, T. and J. Zietlow. (2004). Short-term Financial Management. Australia: Southwestern Press

Mohamad ,N. E. A. B., \& Saad, N. M. B. (2010). Working Capital Management: The Effect of Market Valuation and Profitability in Malaysia. International Journal of Business and Management, 5(11), 140-147. https://doi.org/10.5539/ijbm.v5n11p140.

Pandey, I.M., Gupta, J.P. and Perera, K.L.W. (1997). Working Capital Management: Policies and Practices in Sri Lanka, Journal of Euro-Asian Management, 3(1), 74-97.

Padachi, K. (2006). Trends in Working Capital Management and its Impact on Firms' Performance: An Analysis of Mauritian Small Manufacturing Firms. International Review of Business Research Papers, 2(2), 45-58.

Perera, K. L. W., \& Wickremasinghe, G. B. (2010). Working capital management practices of manufacturing sector companies in Sri Lanka : survey evidence. Investment Management and Financial Innovations, 7(4), 34-38.

Pratap Singh, H., \& Kumar, S. (2014). Working capital management: a literature review and research agenda. Qualitative Research in Financial Markets, 6(2), 173-197.

Pass, C.L., \& Pike, R.H. (1984). An overview of working capital management and corporate financing. Managerial Finance, 10(3), 1-11.https://doi.org/10.1108/eb027318

Pinkowitz, L., Stulz, R., \& Williamson, R. (2006). Does the contribution of corporate cash holdings and dividends to firm value depend on governance? A cross-country analysis. Journal of Finance, 61(6), 2725-2751. https://doi.org/10.1111/j.1540-6261.2006.01003.x

Pinkowitz, L., \& Williamson, R. (2007). What is the market value of a dollar of corporate cash?. Journal of Applied Corporate Finance, 19(3), 74-81. https://doi.org/10.1111/j.1745-6622.2007.00148.x

Sharma, A. K., \& Kumar, S. (2011). Effect of Working Capital Management on Firm Profitability Empirical Evidence from India. Global Business Review, 12(1), 159-173. https://doi.org/10.1177/097215091001200110

Shin, H.H., \& Soenen, L. (1998). Efficiency of working capital and corporate profitability. Financial Practice and Education, 8(2), 37-45

Smith,K.V.(1978). Reading on the Management of Working Capital, West Publishing Company, 3-21.

Vijayakumaran, R. (2015). Capital structure decisions agency conflict and corporate performance: Evidence from Sri Lankan listed manufacturing companies, International Journal of Accounting and Business Finance, 1(1), 1-14. 
Vural, G. (2012). Affects of Working Capital Management on Firm's Performance : Evidence from Turkey, 2(4), 488-495.

Wasiuzzaman, S. (2015). Working capital and firm value in an emerging market. International Journal of Managerial Finance, 11(1), 60-79. https://doi.org/10.1108/IJMF-01-2013-0016

Note: Authors have equally contributed to this research paper and their names are in alphabetical order. 